

1. Divisão de Pesquisa Populacional Coordenação de Pesquisa e Educação, Instituto Nacional de Câncer José Alencar Gomes da Silva - INCA Rio de Janeiro (RJ) Brasil.

2. Programa de Computação Científica, Fundação Oswaldo Cruz - Fiocruz Rio de Janeiro (RJ) Brasil.

3. Departamento de Métodos Quantitativos em Saúde, Escola Nacional de Saúde Pública Sérgio Arouca - ENSP - Fundação Oswaldo Cruz - Fiocruz - Rio de Janeiro (RJ) Brasil.

Submitted: 30 March 2015 Accepted: 27 January 2016.

Study carried out at the Instituto Nacional de Câncer José Alencar Gomes da Silva - INCA - and at the Escola Nacional de Saúde Pública Sérgio Arouca - ENSP Fundação Oswaldo Cruz - Fiocruz Rio de Janeiro (RJ) Brasil.

\section{Factors associated with disease-specific survival of patients with non-small cell lung cancer}

\author{
Mirian Carvalho de Souza1, Oswaldo Gonçalves Cruz², Ana Glória Godoi Vasconcelos ${ }^{3}$
}

\begin{abstract}
Objective: Lung cancer is a global public health problem and is associated with high mortality. Lung cancer could be largely avoided by reducing the prevalence of smoking The objective of this study was to analyze the effects of social, behavioral, and clinical factors on the survival time of patients with non-small cell lung cancer treated at Cancer Hospital I of the José Alencar Gomes da Silva National Cancer Institute, located in the city of Rio de Janeiro, Brazil, between 2000 and 2003. Methods: This was a retrospective hospital cohort study involving 1,194 patients. The 60-month disease-specific survival probabilities were calculated with the Kaplan-Meier method for three stage groups. The importance of the studied factors was assessed with a hierarchical theoretical model after adjustment by Cox multiple regression. Results: The estimated 60-month specificdisease lethality rate was $86.0 \%$. The 60 -month disease-specific survival probability ranged from $25.0 \%$ (stages I/II) to $2.5 \%$ (stage IV). The performance status, the intention to treat, and the initial treatment modality were the major prognostic factors identified in the study population. Conclusions: In this cohort of patients, the disease-specific survival probabilities were extremely low. We identified no factors that could be modified after the diagnosis in order to improve survival. Primary prevention, such as reducing the prevalence of smoking, is still the best method to reduce the number of people who will suffer the consequences of lung cancer.
\end{abstract}

Keywords: Lung neoplasms/epidemiology; Carcinoma, non-small-cell lung; Survival analysis.

\section{INTRODUCTION}

Lung cancer is the most common type of cancer worldwide; it is estimated that, in 2012, there were 1.8 million new cases. ${ }^{(1)}$ In Brazil in 2015, 27,000 new cases were estimated. ${ }^{(2)}$

Although lung cancer has various histological types, the most widely used classification system is that which divides tumors into small cell carcinomas (15\%) and non-small cell carcinomas (85\%). ${ }^{(3)}$

The 60-month survival probability of patients with nonsmall cell lung carcinoma is lower than $15 \%$ in Europe. ${ }^{(4)}$ A study conducted in the United States obtained estimates ranging from $66 \%$ (stage Ia) to $4 \%$ (stage IV)..$^{(5)}$ A study involving patients from a university hospital in the city of Rio de Janeiro, Brazil, found that the 60-month survival probability was $6 \%$, with it being $14 \%$ for the early stages and $5 \%$ for the advanced stages. ${ }^{(6)}$

Among the prognostic factors studied for lung cancer patients ${ }^{(7)}$ are stage, performance status, ${ }^{(8)}$ weight loss, gender, age, smoking, smoking history, quality of life, marital status, depression, and genetic mutations. ${ }^{(6,9-11)}$

Epidemiological studies have indicated that the effects of socioeconomic factors on health outcomes are indirect, occurring through behavioral and clinical factors. In this context, it is important to establish the hierarchy of these factors in determining the occurrence of lung cancer and in the survival probability of patients with this type of cancer. ${ }^{(12,13)}$

The objective of the present article was to analyze the importance of social, behavioral, and clinical factors on the survival time of patients with non-small cell lung cancer treated at Hospital do Câncer I do Instituto Nacional de Câncer José Alencar Gomes da Silva (HCI/INCA, Cancer Hospital I of the José Alencar Gomes da Silva National Cancer Institute), located in the city of Rio de Janeiro, Brazil, between 2000 and 2003.

\section{METHODS}

This was a retrospective observational hospital cohort study in which the object of interest was the time from diagnosis to death from lung cancer or metastasis.

The target population consisted of patients diagnosed with primary non-small cell lung carcinoma, between 2000 and 2003, who were registered in the Registro Hospitalar de Câncer (RHC, Hospital Cancer Registry) of $\mathrm{HCI} / \mathrm{INCA}$, which is a tertiary referral hospital for the treatment of cancer in the state of Rio de Janeiro, Brazil.

Eligible patients were defined as those from the state of Rio de Janeiro, where HCI/INCA is located, in whom diagnosis was confirmed by either anatomic pathological 
or cytological examination of the tumor and who had not been previously treated. The list of patients who met the eligibility criteria was extracted from the RHC of $\mathrm{HCI} / \mathrm{INCA}$, with the primary source of cancer registry information being medical records. At HCI/INCA, medical records were not electronic. To update data on patient survival, we searched the Rio de Janeiro State Mortality Database, and, for patients for whom the information was missing, we conducted an active search according to the $\mathrm{RHC}$ routine. ${ }^{(14)}$ In addition, medical records were abstracted for information about smoking history and performance status, which is measured with scales that are used to evaluate how the disease progresses and affects the daily living abilities of the patient, in order to determine appropriate treatment and prognosis. ${ }^{(8)}$ Patients who had ever smoked were considered smokers.

Of the 1,502 cases of non-small cell lung cancer registered in the RHC between 2000 and 2003, 1,394 lived in the state of Rio de Janeiro. Of those, 200 were excluded because it was impossible to determine disease stage by reviewing the medical records.

To reduce the influence of anticipation bias, ${ }^{(15)}$ all analyses were stratified by clinical stage group, as determined by the tumor-node-metastasis classification system $^{(16)}$ : stages I/II (early stage); stage III; and stage IV. Stages I and II were gathered into one group in order to provide greater stability to the results of the models.
The factors identified in the review of the literature were organized into a hierarchical theoretical model (Figure 1).(1-6) Distal factors included sociodemographic characteristics and family history of cancer; intermediate factors included behavioral characteristics as well as access to and effectiveness of the health care system, all of which are generally influenced by sociodemographic characteristics; and proximal factors included patient clinical characteristics, disease characteristics, and treatment characteristics, all of which can be influenced by the previous level factors. Of the 28 factors identified, 10 were not analyzed because they were unavailable or because they were available in very few medical records. In the categorization of the studied factors, priority was given not only to coherence in the object of study but also to data stability as a function of the sample, especially in relation to stages I/II.

Age at diagnosis was included in all multiple regression models because it is directly related to death (from a biological standpoint), because it characterizes the birth cohort, and because it influences other factors (smoking, occupation, etc.)

The 60-month disease-specific survival probability in lung cancer was estimated with the Kaplan-Meier method, on the basis of the following criteria: i) initial event: diagnosis of lung cancer; ii) final event: death from lung cancer or metastasis; iii) survival time: time from initial to final event or time to loss to follow-up; and iv) censored cases: cases that were lost to follow-up over the 60-month period; cases in



Stage will be used as a stratification variable in order to reduce anticipation bias.

avariables unavailable for analysis.

'Variables unavailable in a high proportion of cases.

Figure 1. Hierarchical theoretical model of prognostic factors and death from lung cancer. 
which death from lung cancer or metastasis was not confirmed; and cases in which patients survived the 60-month follow-up.

Differences between the estimated probability curves were determined via log-rank test. Variables that had a value of $p<0.20$ in the log-rank test were included in the Cox models. ${ }^{(17)}$ The adjusted effects of factors on survival time were calculated, for each stage, by using the Cox model, on the basis of the hierarchical theoretical model proposed in Figure 1.

In the preparation of the models, variables were entered in blocks. First, distal factors were entered; those with a value of $p<0.10$ were maintained in model 1 . Subsequently, intermediate factors were added to model 1 , and the same selection criterion was applied (model 2). The same procedure was repeated for proximal factors, and the final model was obtained. In the modeling process, the previous level factors that lost significance upon inclusion of more proximal-level factors were maintained. The goodness-of-fit of the models was determined by calculating the likelihood ratio, the probability of agreement, and the overall goodness-of-fit. ${ }^{(17)}$

The research project that generated the present article is registered with the research ethics committees of the INCA and the Sérgio Arouca National School of Public Health (Protocol nos. CAAE-012.0.007.031-11 and CAAE-0163.0.031.007-11).

\section{RESULTS}

A comparison of cases included and excluded as per the eligibility criteria indicated no statistically significant differences (chi-square test) in the distribution by gender, level of education, smoking, histological type, or treatment.

The mean age of the 1,194 patients included in the study was 62 years, and it decreased with the severity of tumor stage (stages I/II, 65 years; stage III, 62 years; and stage IV, 60 years). Most subjects were

Table 1. Distribution and 60-month disease-specific survival probability of the study cohort of patients with non-small cell lung cancer by clinical stage, as well as by distal factor and by intermediate factor of the proposed model. Cancer Hospital I, José Alencar Gomes da Silva National Cancer Institute, 2000-2003.

\begin{tabular}{|c|c|c|c|c|c|c|c|c|c|c|c|c|c|c|}
\hline \multirow{4}{*}{$\begin{array}{l}\text { Distal and } \\
\text { intermediate factors }\end{array}$} & \multicolumn{12}{|c|}{ Stage } & \multirow{2}{*}{\multicolumn{2}{|c|}{ Total }} \\
\hline & \multicolumn{4}{|c|}{$\mathrm{I} / \mathrm{II}$} & \multicolumn{4}{|c|}{ III } & \multicolumn{4}{|c|}{ IV } & & \\
\hline & \multirow[t]{2}{*}{$\mathbf{n}$} & \multirow[t]{2}{*}{$\%$} & \multicolumn{2}{|r|}{ SPr } & \multirow[t]{2}{*}{$\mathbf{n}$} & \multirow[t]{2}{*}{$\%$} & \multicolumn{2}{|r|}{ SPr } & \multirow[t]{2}{*}{$\mathbf{n}$} & \multirow[t]{2}{*}{$\%$} & \multicolumn{2}{|r|}{ SPr } & \multirow[t]{2}{*}{$\mathbf{n}$} & \multirow[t]{2}{*}{$\%$} \\
\hline & & & $\%$ & $95 \% \mathrm{CI}$ & & & $\%$ & $95 \% \mathrm{Cl}$ & & & $\%$ & $95 \% \mathrm{Cl}$ & & \\
\hline Total & 207 & 17.3 & 25.0 & $19.1-32.8$ & 506 & 42.4 & 6.7 & $4.5-9.9$ & 481 & 40.3 & 2.5 & $1.3-4.9$ & 1,194 & 100.0 \\
\hline \multicolumn{15}{|l|}{ Distal factor } \\
\hline \multicolumn{15}{|l|}{ Age group, years } \\
\hline $30-49$ & 18 & 8.7 & 41.2 & $23.3-72.7$ & 63 & 12.5 & 7.3 & $2.5-21.8$ & 72 & 15.0 & 0.0 & $\mathrm{~N} / \mathrm{A}$ & 153 & 12.8 \\
\hline $50-59$ & 41 & 19.8 & 32.5 & $20.0-52.9$ & 128 & 25.3 & 8.7 & $4.5-16.8$ & 144 & 29.9 & 0.8 & $0.1-5.9$ & 313 & 26.2 \\
\hline $60-69$ & 67 & 32.4 & 22.4 & $13.0-38.4$ & 189 & 37.4 & 8.6 & $4.9-14.8$ & 179 & 37.2 & 4.9 & $2.3-10.6$ & 435 & 36.4 \\
\hline $70-99$ & 81 & 39.1 & 19.0 & $11.1-32.4$ & 126 & 24.9 & 1.2 & $0.2-8.3$ & 86 & 17.9 & 2.5 & $0.4-15.2$ & 293 & 24.5 \\
\hline \multicolumn{15}{|l|}{ Gender } \\
\hline Female & 68 & 32.9 & 29.3 & $19.2-44.8$ & 134 & 26.5 & 5.9 & $2.7-12.8$ & 138 & 28.7 & 2.9 & $1.0-8.8$ & 340 & 28.5 \\
\hline Male & 139 & 67.1 & 23.1 & 16.3-32.7 & 372 & 73.5 & 7.0 & $4.5-11.0$ & 343 & 71.3 & 2.4 & $1.1-5.5$ & 854 & 71.5 \\
\hline \multicolumn{15}{|l|}{ Intermediate factor } \\
\hline \multicolumn{15}{|l|}{ Smoking ${ }^{a}$} \\
\hline Never smoking & 20 & 9.7 & 28.7 & $13.8-59.7$ & 23 & 4.5 & 5.3 & $0.8-35.9$ & 52 & 10.8 & 9.6 & $3.8-24.3$ & 95 & 8.0 \\
\hline $\begin{array}{l}\text { Current or } \\
\text { former smoking }\end{array}$ & 185 & 89.4 & 24.6 & $18.4-33.0$ & 480 & 94.9 & 6.8 & $4.6-10.1$ & 422 & 87.7 & 1.5 & $0.6-3.9$ & 1,087 & 92.0 \\
\hline \multicolumn{15}{|c|}{ Smoking history, pack-years ${ }^{c}$} \\
\hline Up to 51 & 86 & 46.5 & 28.0 & $19.2-40.7$ & 251 & 52.3 & 6.6 & $3.7-11.6$ & 225 & 53.3 & 1.4 & $0.4-5.5$ & 562 & 55.3 \\
\hline $52-103$ & 59 & 31.9 & 20.7 & $11.6-37.0$ & 143 & 29.8 & 5.4 & $2.5-11.8$ & 128 & 30.3 & 1.4 & $0.2-8.2$ & 330 & 32.4 \\
\hline $104-360$ & 25 & 13.5 & 21.7 & $9.2-50.9$ & 59 & 12.3 & 13.2 & $6.2-27.9$ & 41 & 9.7 & 3.0 & $0.4-20.5$ & 125 & 12.3 \\
\hline \multicolumn{15}{|c|}{ Diagnosis occurring prior to admission to $\mathrm{HCl} / \mathrm{INCA}$} \\
\hline Yes & 44 & 21.3 & 35.3 & $22.8-54.6$ & 158 & 31.2 & 11.3 & $6.7-18.9$ & 151 & 31.4 & 2.7 & $0.9-8.2$ & 353 & 29.6 \\
\hline No & 163 & 78.7 & 22.5 & $16.2-31.2$ & 348 & 68.8 & 4.5 & $2.5-8.0$ & 330 & 68.6 & 2.5 & $1.1-5.7$ & 841 & 70.4 \\
\hline \multicolumn{15}{|c|}{ Distance from home to $\mathrm{HCl} / \mathrm{INCA}, \mathrm{km}$} \\
\hline$\leq 10.00$ & 54 & 26.1 & 26.9 & $16.5-43.9$ & 131 & 25.9 & 4.7 & $1.8-12.2$ & 119 & 24.7 & 1.2 & $0.2-8.4$ & 304 & 25.5 \\
\hline $10.01-20.00$ & 55 & 26.6 & 31.2 & $19.7-49.3$ & 134 & 26.5 & 4.5 & $1.7-11.6$ & 144 & 29.9 & 4.2 & $1.6-10.8$ & 333 & 27.9 \\
\hline $20.01-30.00$ & 31 & 15.0 & 9.6 & $2.7-33.9$ & 88 & 17.4 & 11.1 & $5.8-21.4$ & 76 & 15.8 & 3.2 & $0.8-12.4$ & 195 & 16.3 \\
\hline $30.01-40.00$ & 25 & 12.1 & 10.8 & $2.9-39.8$ & 61 & 12.1 & 2.3 & $0.3-16.1$ & 60 & 12.5 & 0.0 & N/A & 146 & 12.2 \\
\hline$>40.00$ & 42 & 20.3 & 36.1 & $23.2-56.2$ & 92 & 18.2 & 10.5 & $5.2-21.1$ & 82 & 17.0 & 3.3 & $0.9-12.9$ & 216 & 18.1 \\
\hline
\end{tabular}

SPr: survival probability; and HCI/INCA: Hospital do Câncer I, Instituto Nacional de Câncer José Alencar Gomes da Silva. ${ }^{a}$ Data unavailable in 12 cases. ${ }^{b}$ Category corresponding to ever smokers. 'Data unavailable in 82 cases. 
male and smokers; in stage III, the smoker/nonsmoker ratio reached its maximum value (20.9:1.0). The mean smoking history was 60 pack-years, and less than one third of the patients had a confirmed diagnosis prior to admission to $\mathrm{HCI}$ /INCA (Table 1 ).

At diagnosis, more than half of the patients in stages I/II and III presented with restrictions for performing vigorous physical activities. The most common first treatment was radiotherapy, and, in stages I/II, surgery was the first treatment in only one fourth of the cases. Adenocarcinoma predominated in stages I/II and stage IV, followed by squamous carcinoma, chiefly in stage III (Table 2).

By the end of the 60-month follow-up, 1,027 patients $(86.0 \%)$ had died from lung cancer, 66 (5.5\%) had died from other causes, 70 (5.9\%) had survived, and $31(2.6 \%)$ had been lost. The estimated 12-month and 60 -month disease-specific survival probabilities were $32.7 \%(95 \% \mathrm{CI}: 30.0-35.5 \%)$ and $7.9 \%(95 \%$ CI: 6.3-9.7\%), respectively. The median survival time was estimated to be 17.7 months for stages I/II, 8.0 months for stage III, and 5.5 months for stage IV.

Patients with stage IV disease who were nonsmokers had a better prognosis than did those who were smokers/former smokers. Being admitted to $\mathrm{HCI} /$ INCA with a confirmed diagnosis doubled the survival probability of stage III patients (Table 1). Survival decreased with increasing limitation as assessed by the performance status scale, regardless of stage. Among the patients for whom information on tumor location was available, stage I/II and stage III patients had a better prognosis (Table 2 ).

In the modeling process, the cases with missing values for the variables included in the final models were excluded to allow comparability between the models of the different levels. We excluded 20 stage

Table 2. Distribution and 60-month disease-specific survival probability of the study cohort of patients with non-small cell lung cancer by clinical stage and by proximal factor of the proposed model. Cancer Hospital I, José Alencar Gomes da Silva National Cancer Institute, 2000-2003.

\begin{tabular}{|c|c|c|c|c|c|c|c|c|c|c|c|c|c|c|}
\hline \multirow[t]{4}{*}{ Proximal factor } & \multicolumn{12}{|c|}{ Stage } & \multicolumn{2}{|c|}{ Total } \\
\hline & \multicolumn{4}{|c|}{$\mathrm{I} / \mathrm{II}$} & \multicolumn{4}{|c|}{ III } & \multicolumn{4}{|c|}{ IV } & \multirow{3}{*}{$\mathbf{n}$} & \multirow{3}{*}{$\%$} \\
\hline & \multirow[t]{2}{*}{$n$} & \multirow[t]{2}{*}{$\%$} & \multicolumn{2}{|r|}{ SPr } & \multirow[t]{2}{*}{$\bar{n}$} & \multirow[t]{2}{*}{$\%$} & \multicolumn{2}{|r|}{ SPr } & \multirow[t]{2}{*}{$n$} & \multirow[t]{2}{*}{$\%$} & \multicolumn{2}{|r|}{ SPr } & & \\
\hline & & & $\%$ & $95 \% \mathrm{Cl}$ & & & $\%$ & $95 \% \mathrm{Cl}$ & & & $\%$ & $95 \% \mathrm{Cl}$ & & \\
\hline \multicolumn{15}{|l|}{ Performance status ${ }^{\mathrm{a}}$} \\
\hline Fully active & 34 & 16.4 & 53.5 & $38.2-74.9$ & 39 & 7.7 & 10.7 & $3.7-30.7$ & 48 & 10.0 & 6.3 & $1.8-22.2$ & 121 & 11.6 \\
\hline $\begin{array}{l}\text { Limited in } \\
\text { vigorous activities }\end{array}$ & 114 & 55.1 & 24.7 & $17.3-35.2$ & 308 & 60.9 & 8.0 & $5.2-12.2$ & 233 & 48.4 & 2.5 & $1.1-5.9$ & 655 & 62.8 \\
\hline $\begin{array}{l}\text { Able of self-care } \\
\text { but unable to } \\
\text { work }\end{array}$ & 39 & 18.8 & 0.0 & N/A & 93 & 18.4 & 1.3 & $0.2-9.0$ & 105 & 21.8 & 1.3 & $0.2-8.8$ & 237 & 22.7 \\
\hline $\begin{array}{l}\text { Bedridden at } \\
\text { least } 50 \% \text { of the } \\
\text { day }\end{array}$ & 0 & 0.0 & N/A & N/A & 8 & 1.6 & 0.0 & N/A & 22 & 4.6 & 0.0 & N/A & 30 & 2.9 \\
\hline \multicolumn{15}{|l|}{ Tumor laterality } \\
\hline Unilateral & 192 & 92.8 & 26.2 & $20.0-34.3$ & 467 & 92.3 & 6.5 & $4.4-9.6$ & 423 & 87.9 & 2.9 & $1.5-5.5$ & 1,082 & 98.5 \\
\hline Bilateral & 1 & 0.5 & 0.0 & N/A & 4 & 0.8 & 25.0 & $4.6-100.0$ & 11 & 2.3 & 0.0 & N/A & 16 & 1.5 \\
\hline \multicolumn{15}{|c|}{ Availability of detailed information on tumor location } \\
\hline Yes & 165 & 79.7 & 28.2 & 21.4-37.2 & 305 & 60.3 & 7.9 & $5.1-12.4$ & 236 & 49.1 & 3.0 & $1.2-7.2$ & 706 & 59.1 \\
\hline No & 42 & 20.3 & 10.7 & $3.7-30.7$ & 201 & 39.7 & 4.6 & $2.1-9.9$ & 245 & 50.9 & 2.3 & $0.9-5.9$ & 488 & 40.9 \\
\hline \multicolumn{15}{|c|}{ Initial treatment intent ${ }^{c}$} \\
\hline Curative & 132 & 78.6 & 33.8 & $25.9-44.3$ & 231 & 55.8 & 9.7 & $6.2-15.3$ & 82 & 22.9 & 4.8 & $1.4-16.5$ & 445 & 47.3 \\
\hline Palliative & 22 & 13.1 & 0.0 & N/A & 149 & 36.0 & 2.7 & $0.9-8.1$ & 275 & 76.8 & 2.4 & $1.0-5.7$ & 446 & 47.4 \\
\hline Neoadjuvant & 14 & 8.3 & 33.8 & $13.5-84.5$ & 34 & 8.2 & 13.6 & $5.5-33.8$ & 1 & 0.3 & 0.0 & $\mathrm{~N} / \mathrm{A}$ & 49 & 5.2 \\
\hline \multicolumn{15}{|c|}{ Initial treatment modality } \\
\hline Surgery & 52 & 25.1 & 63.5 & $50.3-80.3$ & 9 & 1.8 & 28.6 & $8.9-92.2$ & 9 & 1.9 & 42.9 & $18.2-100.0$ & 70 & 5.9 \\
\hline Radiotherapy & 89 & 43.0 & 6.7 & $2.2-20.2$ & 247 & 48.8 & 5.7 & $3.1-10.5$ & 233 & 48.4 & 1.1 & $0.3-4.5$ & 569 & 47.7 \\
\hline Chemotherapy & 38 & 18.4 & 30.0 & $17.2-52.5$ & 181 & 35.8 & 9.1 & $5.3-15.5$ & 158 & 32.8 & 2.6 & $0.9-7.8$ & 377 & 31.6 \\
\hline No treatment & 28 & 13.5 & 0.0 & $\mathrm{~N} / \mathrm{A}$ & 69 & 13.6 & 0.0 & N/A & 81 & 16.8 & 0.0 & $\mathrm{~N} / \mathrm{A}$ & 178 & 14.9 \\
\hline \multicolumn{15}{|l|}{ Histological type } \\
\hline Adenocarcinoma & 87 & 42.0 & 30.6 & $21.3-43.9$ & 198 & 39.1 & 6.8 & $3.7-12.6$ & 237 & 49.3 & 2.9 & $1.3-6.9$ & 522 & 43.7 \\
\hline $\begin{array}{l}\text { Squamous } \\
\text { carcinoma }\end{array}$ & 81 & 39.1 & 17.3 & $9.9-30.2$ & 207 & 40.9 & 6.7 & $3.7-12.2$ & 130 & 27.0 & 1.8 & $0.3-10.3$ & 418 & 35.0 \\
\hline $\begin{array}{l}\text { Other } \\
\text { carcinomas }\end{array}$ & 39 & 18.8 & 28.2 & $15.9-50.2$ & 101 & 20.0 & 6.6 & $2.6-16.6$ & 114 & 23.7 & 2.3 & $0.6-9.1$ & 254 & 21.3 \\
\hline
\end{tabular}

SPr: survival probability. a Data unavailable in 151 cases. ${ }^{b}$ Data unavailable in 96 cases. ${ }^{\mathrm{c}}$ Data unavailable in 76 cases. 
I/II cases, 108 stage III cases, and 75 stage IV cases. Excluded and analyzed cases were compared, and no statistically significant differences were observed for the variables gender, age, level of education, race, marital status, smoking, histological type, treatment, vital status, or follow-up period.

In stages I/II, age, gender, performance status, detailed tumor location, histological type, initial treatment intent, and initial treatment modality proved to be important prognostic factors in the crude analysis of the Cox models and were used in the hierarchical modeling.

None of the intermediate factors were included in the multiple regression model of stages I/II ( $p>0.20$ in the log-rank test). When the proximal factors were added to model 1 , the risk estimates decreased. The risk of death, adjusted for the other variables of the final model, was 2.34 times higher among patients who were unable to perform work activities than among those who were active, was twice as high among those for whom information on tumor location was unavailable as among those for whom this information was available, and was thirteen times higher among untreated patients than among operated patients. The risk of death associated with the use of radiotherapy or chemotherapy was high when compared with that related to surgery (Table 3 ).

In stage III, the prognostic factors used in the hierarchical modeling were age, diagnosis occurring prior to admission, distance from home to HCI/INCA, performance status, tumor laterality, tumor location, initial treatment intent, and initial treatment modality.
In the adjusted model for stage III, there were no differences in the estimates when the intermediate factors were added to model 1 ; however, when the proximal factors were included, the age-related risk estimate decreased. The effect of diagnosis occurring prior to admission increased when the proximal factors were included. The final model showed an excess risk of death of $70.0 \%$, adjusted for the other factors, among the patients who had not been given a diagnosis prior to admission (Table 4).

Performance status maintained a strong association with outcome in the final model and showed an increasing gradient of risk of death/worsening of the patient's physical state. Patients who underwent palliative treatments had a risk of death, adjusted for the other factors in the final model, 2.48 times that of those who underwent curative treatments. Among the untreated patients, this estimate was even higher (Table 4).

In stage IV, the study characteristics gender, smoking, smoking history, diagnosis occurring prior to admission, distance from home to HCI/INCA, performance status, tumor laterality, histological type, initial treatment intent, and initial treatment modality were used in the hierarchical modeling. The age-related risk estimate decreased and gained statistical significance when the proximal factors were included in the final model. The effect associated with smoking decreased and lost statistical significance when the proximal factors were entered. This behavior probably occurs because the effect of smoking is mediated by proximal factors. Adjusted for the other factors, the risk of death by

Table 3. Results of the hierarchical Cox model of patients with stage I/II non-small cell lung cancer. Cancer Hospital I, José Alencar Gomes da Silva National Cancer Institute, 2000-2003.

\begin{tabular}{|c|c|c|}
\hline Characteristic studied & $\begin{array}{c}\text { Model } 1 \\
\text { HR }(95 \% \text { CI) }\end{array}$ & $\begin{array}{l}\text { Final model } \\
\text { HR }(95 \% \mathrm{CI})\end{array}$ \\
\hline Age & $1.03^{a}(1.01-1.05)$ & $1.01(0.99-1.03)$ \\
\hline \multicolumn{3}{|l|}{ Gender } \\
\hline Female & 1.00 & 1.00 \\
\hline Male & $1.43^{\mathrm{b}}(0.98-2.09)$ & $1.28(0.87-1.90)$ \\
\hline \multicolumn{3}{|l|}{ Performance status } \\
\hline Fully active, able to perform all activities & & 1.00 \\
\hline Limited in vigorous activities & & $1.23(0.66-2.32)$ \\
\hline Able of self-care but unable to work & & $2.34^{\mathrm{a}}(1.14-4.81)$ \\
\hline \multicolumn{3}{|c|}{ Availability of detailed information on tumor location } \\
\hline Yes & & 1.00 \\
\hline No & & $2.03^{\mathrm{a}}(1.29-3.20)$ \\
\hline \multicolumn{3}{|l|}{ Initial treatment modality } \\
\hline Surgery & & 1.00 \\
\hline Radiotherapy & & $5.13^{a}(2.59-10.18)$ \\
\hline Chemotherapy & & $2.70^{a}(1.30-5.57)$ \\
\hline No treatment & & $13.15^{\mathrm{a}}(6.39-27.06)$ \\
\hline$\%$ of the explained variability $\left(R^{2}\right)$ & 8.22 & 44.42 \\
\hline Concordance probability, \% & 0.62 & 0.76 \\
\hline P-value of the deviance test (ANOVA) & & $<0.001$ \\
\hline
\end{tabular}

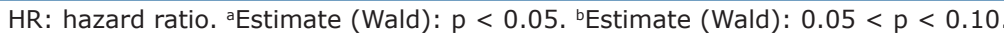


Table 4. Results of the hierarchical Cox model of patients with stage III non-small cell lung cancer. Cancer Hospital I, José Alencar Gomes da Silva National Cancer Institute, 2000-2003.

\begin{tabular}{|c|c|c|c|}
\hline Characteristic studied & $\begin{array}{c}\text { Model } 1 \\
\text { HR }(95 \% \text { CI) }\end{array}$ & $\begin{array}{c}\text { Model } 2 \\
\text { HR }(95 \% \text { CI) }\end{array}$ & $\begin{array}{l}\text { Final model } \\
\text { HR }(95 \% \mathrm{Cl})\end{array}$ \\
\hline Age & $1.02^{\mathrm{a}}(1.01-1.03)$ & $1.02^{\mathrm{a}}(1.01-1.03)$ & $1.01(1.00-1.02)$ \\
\hline \multicolumn{4}{|l|}{ Diagnosis occurring prior to admission to $\mathrm{HCl} / \mathrm{INCA}$} \\
\hline Yes & & 1.00 & 1.00 \\
\hline No & & $1.63^{\mathrm{a}}(1.30-2.06)$ & $1.70^{\mathrm{a}}(1.34-2.15)$ \\
\hline \multicolumn{4}{|l|}{ Distance from $\mathrm{HCl} / \mathrm{INCA}$ to home, $\mathrm{km}$} \\
\hline$\leq 10.00$ & & 1.00 & 1.00 \\
\hline $10.01-20.00$ & & $0.86(0.64-1.16)$ & $0.88(0.65-1.19)$ \\
\hline $20.01-30.00$ & & $0.75^{\mathrm{b}}(0.54-1.04)$ & $0.71^{\mathrm{a}}(0.43-0.85)$ \\
\hline $30.01-40.00$ & & $1.10(0.77-1.58)$ & $0.95(0.65-1.37)$ \\
\hline$>40.00$ & & $0.71^{\mathrm{a}}(0.52-0.99)$ & $0.64^{\mathrm{a}}(0.46-0.90)$ \\
\hline \multicolumn{4}{|l|}{ Performance status } \\
\hline Fully active, able to perform all activities & & & 1.00 \\
\hline Limited in vigorous activities & & & $1.33(0.89-2.00)$ \\
\hline Able of self-care but unable to work & & & $2.70^{\mathrm{a}}(1.73-4.21)$ \\
\hline Bedridden at least $50 \%$ of awake hours & & & $4.56^{a}(1.93-10.75)$ \\
\hline \multicolumn{4}{|l|}{ Tumor laterality } \\
\hline Unilateral & & & 1.00 \\
\hline Bilateral & & & $0.32^{b}(0.10-1.02)$ \\
\hline \multicolumn{4}{|l|}{ Initial treatment intent } \\
\hline Curative & & & 1.00 \\
\hline Palliative & & & $2.48^{\mathrm{a}}(1.93-3.21)$ \\
\hline Neoadjuvant & & & $0.97(0.63-1.48)$ \\
\hline No treatment & & & $3.67^{\mathrm{a}}(2.56-5.25)$ \\
\hline$\%$ of the explained variability $\left(R^{2}\right)$ & 2.62 & 8.37 & 32.86 \\
\hline Concordance probability, \% & 0.56 & 0.60 & 0.71 \\
\hline P-value of the deviance test (ANOVA) & & $<0.001$ & $<0.001$ \\
\hline
\end{tabular}

HR: hazard ratio; and HCI/INCA: Hospital do Câncer I, Instituto Nacional de Câncer José Alencar Gomes da Silva. ${ }^{a}$ Estimate (Wald): $p<0.05$. ${ }^{b}$ Estimate (Wald): $0.05<p<0.10$.

the end of the 60-month follow-up was found to be $50.0 \%$ higher among those who had not been given a diagnosis prior to admission. Those who lived within a radius of $20-30 \mathrm{~km}$ of $\mathrm{HCI} / \mathrm{INCA}$ had an adjusted risk of death that was $28.0 \%$ lower than that for those who lived closer to HCI/INCA (Table 5).

Performance status maintained a strong association with outcome after adjustment and showed an increasing gradient of risk of death/worsening of the patient's physical state. The risks associated with nonsurgical treatments, as compared with surgical treatments, are extremely high in that stage. In addition, the risk of death by the end of the 60-month follow-up is estimated to be eight times higher among untreated patients than among operated patients (Table 5).

The inclusion of the proximal factors in the more distal-level models significantly increased the likelihood ratio of the final models, regardless of stage. In addition, the probability of agreement of these models can be classified as very good in stages I/II and stage III and as coherent in stage IV. The all-level adjusted models were significantly different from the null model $(p<0.001)$ in the three stages analyzed (Tables 2, 3, and 4).

\section{DISCUSSION}

Among the factors evaluated, performance status, initial treatment intent, and initial treatment modality stood out for influencing the survival time of patients with non-small cell lung cancer treated at $\mathrm{HCI} / \mathrm{INCA}$ between 2000 and 2003, in all stage groups. The magnitudes and directions of the estimated effects related to these factors in the present study are consistent with those reported in other studies and will be addressed below. ${ }^{(6,18,19)}$

Survival studies of lung cancer patients commonly involve clinical trial patients. A review of the literature revealed two survival studies of patients with nonsmall cell lung cancer, both of which were conducted in the city of Rio de Janeiro, Brazil: one in a public hospital, in which 60-month survival probabilities were estimated ${ }^{(6)}$; and one in a private clinic, $_{(19)}$ in which 24-month survival probabilities were estimated.

The predominance of advanced stage disease (stage IV $40.3 \%)$, males (71.5\%), and smokers (92.0\%) observed in the present study is consistent with the characteristics of other study populations. $(1,6,18-20)$

Results that are consistent and in agreement with findings of previous studies were observed for the 
Table 5. Results of the hierarchical Cox model of patients with stage IV non-small cell lung cancer. Cancer Hospital I, José Alencar Gomes da Silva National Cancer Institute, 2000-2003.

\begin{tabular}{|c|c|c|c|}
\hline Characteristic studied & $\begin{array}{c}\text { Model } 1 \\
\text { HR }(95 \% \mathrm{Cl})\end{array}$ & $\begin{array}{c}\text { Model } 2 \\
\text { HR }(95 \% \mathrm{CI})\end{array}$ & $\begin{array}{l}\text { Final model } \\
\text { HR ( } 95 \% \mathrm{CI})\end{array}$ \\
\hline Age & $0.99(0.98-1.00)$ & $0.99(0.98-1.00)$ & $0.98^{\mathrm{a}}(0.97-0.99)$ \\
\hline \multicolumn{4}{|l|}{ Gender } \\
\hline Female & 1.00 & 1.00 & 1.00 \\
\hline Male & $1.21^{\mathrm{c}}(0.97-1.52)$ & $1.13(0.89-1.43)$ & $1.11(0.87-1.41)$ \\
\hline \multicolumn{4}{|l|}{ Smoking } \\
\hline Never smoking & & 1.00 & 1.00 \\
\hline Current or former smoking ${ }^{b}$ & & $1.46^{\mathrm{a}}(1.03-2.07)$ & $1.23(0.86-1.77)$ \\
\hline \multicolumn{4}{|l|}{ Diagnosis occurring prior to admission to $\mathrm{HCl} / \mathrm{INCA}$} \\
\hline Yes & & 1.00 & 1.00 \\
\hline No & & $1.39^{a}(1.12-1.73)$ & $1.50^{a}(1.19-1.88)$ \\
\hline \multicolumn{4}{|l|}{ Distance from $\mathrm{HCl} /$ INCA to home, $\mathrm{km}$} \\
\hline$\leq 10.00$ & & 1.00 & 1.00 \\
\hline $10.01-20.00$ & & $0.79(0.60-1.05)$ & $0.83(0.63-1.10)$ \\
\hline $20.01-30.00$ & & $0.79(0.57-1.08)$ & $0.72^{\mathrm{a}}(0.52-0.99)$ \\
\hline $30.01-40.00$ & & $1.18(0.82-1.69)$ & $1.00(0.69-1.45)$ \\
\hline$>40.00$ & & $0.76^{c}(0.55-1.04)$ & $0.85(0.62-1.18)$ \\
\hline \multicolumn{4}{|l|}{ Performance status } \\
\hline Fully active, able to perform all activities & & & 1.00 \\
\hline Limited in vigorous activities & & & $1.46^{\mathrm{a}}(1.04-2.06)$ \\
\hline Able of self-care but unable to work & & & $2.58^{\mathrm{a}}(1.72-3.85)$ \\
\hline Bedridden at least $50 \%$ of awake hours & & & $3.87^{a}(2.24-6.68)$ \\
\hline \multicolumn{4}{|l|}{ Initial treatment modality } \\
\hline Surgery & & & 1.00 \\
\hline Radiotherapy & & & $4.70^{\mathrm{a}}(1.70-12.97)$ \\
\hline Chemotherapy & & & $3.28^{\mathrm{a}}(1.20-9.03)$ \\
\hline No treatment & & & $8.03^{\mathrm{a}}(2.85-22.66)$ \\
\hline$\%$ of the explained variability $\left(R^{2}\right)$ & 1.21 & 6.14 & 25.68 \\
\hline Concordance probability, \% & 0.53 & 0.58 & 0.69 \\
\hline P-value of the deviance test (ANOVA) & & $<0.001$ & $<0.001$ \\
\hline
\end{tabular}

HR: hazard ratio; and HCI/INCA: Hospital do Câncer I, Instituto Nacional de Câncer José Alencar Gomes da Silva.

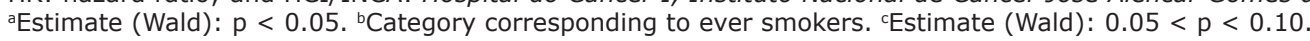

distribution of the study population by smoking history (mean, 60 pack-years), ${ }^{(6)}$ performance status (approximately $90.0 \%$ were limited $),(6,18,19)$ and histological type (more than $40.0 \%$ had adenocarcinoma). $(5,18,20)$

The median estimated survival time was slightly higher than that found in the study conducted in a public hospital in Rio de Janeiro, for all stages. ${ }^{(6)}$ It is likely that, because HCI/INCA is an oncology referral center, it has a health care infrastructure that favors a better prognosis, in comparison with the other public hospital not specializing in oncology. In contrast, the low proportion of operated patients, especially stage I/II patients, indicates limited access to this treatment modality.

The 60-month survival probabilities below $25.0 \%$ found in most of the analysis categories in stages I/ II illustrate how devastating cancer is, regardless of what factors are evaluated, even when the disease is diagnosed in early stages. This finding underscores the importance of primary prevention with two major strategies: encouraging smoking cessation and increasing young people's awareness regarding the dangers of smoking in order to prevent them from acquiring this behavior.

In the evaluation of prognostic factors through the use of the Cox models, results that are consistent with those of other studies were observed for performance status, ${ }^{(18)}$ that is, patients who are more limited have a lower survival probability.

Regarding initial treatment intent and initial treatment modality, the adjusted results of the final models of the present study are consistent with what is expected in oncology, ${ }^{(21,22)}$ that is, survival probabilities are higher among those initially treated with curative intent and among those treated with surgery, which, for lung cancer, is the treatment modality that is most likely to result in a cure.

In stage IV, a mediation effect of smoking was observed for the proximal factors. Considering that variables are entered in blocks, it is impossible to determine which factor is responsible for this effect. ${ }^{(13)}$ 
The results associated with the distance from the patient's home to $\mathrm{HCI} / \mathrm{INCA}$ can be explained on the basis of how the health care system in the state of Rio de Janeiro was organized in terms of lung cancer treatment during the study period. A medical referral, together with test results indicating the presence of a malignant tumor, was required for admission to $\mathrm{HCI} / \mathrm{INCA}$. Patients who lived outside the city of Rio de Janeiro and were referred to HCI/INCA usually benefited from a free shuttle service organized and provided by each municipal government. In general, this service facilitated continuation of treatment and follow-up. Perhaps other ways of evaluating access to the hospital in relation to place of residence, taking into account the route traveled and the transport used as reported by patients, can provide survival analysis results that are more consistent.

In the present study, the incompleteness of the medical records limited the use of some factors in the model proposed in Figure 1 and case inclusion in the analyses. Since the clinical stage was not recorded, we lost $14.3 \%$ of the eligible cases, which affected the stability of the estimates for some analysis categories. An evaluation of cases included and excluded on the basis of missing information revealed a statistically significant difference regarding treatment-approximately
$50.0 \%$ of the patients excluded from the analysis had not been treated, whereas among the cases analyzed, the proportion was $14.9 \%$. This loss could influence the results obtained, but it is impossible to determine the magnitude of this effect because we do not know the stage of the patients who were not analyzed. Progressive improvement in the quality of data entry into medical records should be encouraged, since these documents are often used as a source for database building. Despite the limitations inherent to retrospective studies that use medical records, such studies are of great value in increasing knowledge about disease involvement in populations that are treated at health care clinics.

In summary, it can be noted that the estimated 60-month disease-specific survival probabilities were very low, even in stages I/II. In addition, we identified no factors that could be modified after the diagnosis in order to improve survival. Lung cancer is a silent disease whose symptoms are associated with other less lethal diseases, which can lead to a delay in diagnosis in relation to the natural history of the disease. The best method to reduce the number of people who will suffer the consequences of lung cancer is primary prevention, reducing smoking.

\section{REFERENCES}

1. Ferlay J, Soerjomataram I, Ervik M, Dikshit R, Eser S, Mathers C Rebelo M, Parkin DM, Forman D, Bray, F. GLOBOCAN 2012 v1.0, Cancer incidence and mortality worldwide. IARC CancerBase [serial on the Internet]. 2013 [cited 2015 Jul 1];11. Lyon, France: International Agency for Research on Cancer; 2013. Available from http://globocan.iarc.fr

2. Instituto Nacional de Câncer José Alencar Gomes da Silva. Estimativa 2014: Incidência de câncer no Brasil. Rio de Janeiro: INCA; 2014

3. Travis WD. Pathology of lung cancer. Clin Chest Med 2011;32(4):669-92. http://dx.doi.org/10.1016/j.ccm.2011.08.005

4. Verdecchia A, Francisci S, Brenner H, Gatta G, Micheli A, Mangone $\mathrm{L}$, et al. Recent cancer survival in Europe: a 2000-02 period analysis of EUROCARE-4 data. Lancet Oncol. 2007;8(9):784-96. http:// dx.doi.org/10.1016/S1470-2045(07)70246-2

5. Yang P, Allen MS, Aubry MC, Wampfler JA, Marks RS, Edell ES, et al. Clinical features of 5,628 primary lung cancer patients: experience at Mayo Clinic from 1997 to 2003. Chest. 2005;128(1):452-62. http://dx.doi.org/10.1378/chest.128.1.452

6. Mora P. Análise de sobrevida em pacientes com câncer de pulmão [dissertation]. Rio de Janeiro: Universidade Federal do Rio de Janeiro; 2004

7. León-Atance P, Moreno-Mata N, González-Aragoneses F, Ca-izaresCarretero MÁ, García-Jiménez MD, Genovés-Crespo $M$, et al. Multicenter analysis of survival and prognostic factors in pathologic stage I non-small-cell lung cancer according to the new 2009 TNM classification. Arch Bronconeumol. 2011;47(9):441-6. http://dx.doi. org/10.1016/j.arbres.2011.04.004

8. Zubrod CG, Schneiderman M, Frei III E. Brindley C. Lennard Gold G, Shnider B, et al. Appraisal of methods for the study of chemotherapy of cancer in man: Comparative therapeutic trial of nitrogen mustard and triethylene thiophosphoramide. J Chron Dis. 1960;11(1):7-33. http://dx.doi.org/10.1016/0021-9681(60)90137-5

9. Brundage MD, Davies D, Mackillop WJ. Prognostic factors in non-small cell lung cancer: a decade of progress. Chest 2002;122(3):1037-57. http://dx.doi.org/10.1378/chest.122.3.1037

10. Soria JC, Massard C, Le Chevalier T. Should progressionfree survival be the primary measure of efficacy for advanced
NSCLC therapy? Ann Oncol. 2010;21(12):2324-32. http://dx.doi. org/10.1093/annonc/mdq204

11. Jazieh AR, Hussain M, Howington JA, Spencer HJ, Husain M, Grismer JT, et al. Prognostic factors in patients with surgically resected stages I and II non-small cell lung cancer. Ann Thorac Surg. 2000;70(4):1168-71. http://dx.doi.org/10.1016/S00034975(00)01529-0

12. Victora CG, Huttly SR, Fuchs SC, Olinto MT. The role of conceptua frameworks in epidemiological analysis: a hierarchical approach Int J Epidemiol. 1997;26(1):224-7. http://dx.doi.org/10.1093/ ije/26.1.224

13. Lima S, Carvalho ML, Vasconcelos AG. Proposal for a hierarchical framework applied to investigation of risk factors for neonatal mortality [Article in Portuguese]. Cad Saude Publica. 2008;24(8)1910-6.

14. Instituto Nacional de Câncer José Alencar Gomes da Silva. Registros Hospitalares de Câncer - planejamento e gestão. Vol 1. 2nd ed. Rio de Janeiro: INCA; 2010.

15. Szklo M, Nieto FJ. Epidemiology: beyond the basics. 2nd ed Sudbury (MA): Jones \& Bartlett Learning; 2007.

16. Sobin LH, Wittekind Ch, editors. TNM: classificação de tumores malignos. 6th ed. Rio de Janeiro: INCA; 2004.

17. Carvalho MS, Andreozzi VL, Codeço CT, Campos DP, Barbosa MT, Shikamura SE. Análise de sobrevivência: teoria e aplicações em saúde. 2nd ed. Rio de Janeiro: Fiocruz; 2011.

18. Kawaguchi T, Takada M, Kubo A, Matsumura A, Fukai S, Tamura $A$, et al. Performance status and smoking status are independent favorable prognostic factors for survival in non-small cell lung cancer: a comprehensive analysis of 26,957 patients with NSCLC $J$ Thorac Oncol. 2010;5(5):620-30. http://dx.doi.org/10.1097/ JTO.0b013e3181d2dcd9

19. Araujo L, Baldotto C, Zukin M, Vieira F, Victorino A, Rocha $V R$, et al. Survival and prognostic factors in patients with nonsmall cell lung cancer treated in private health care. Rev Bras Epidemiol. 2014;17(4):1001-1014. http://dx.doi.org/10.1590/18094503201400040017

20. Jatoi A, Novotny P, Cassivi S, Clark MM, Midthun D, Patten CA, et al. Does marital status impact survival and quality of life in patients 
with non-small cell lung cancer? Observations from the mayo clinic lung cancer cohort. Oncologist. 2007;12(12):1456-63. http://dx.doi. org/10.1634/theoncologist.12-12-1456

21. DeVita Jr VT, Lawrence TS, Rosenberg SA, DePinho RA, Weinberg RA, editors. Cancer: principles \& practice of oncology. 9th ed.
Philadelphia (PA): Wolters Kluwer Health/Lippincott Williams \& Wilkins; 2011.

22. Minna JD. Neoplasias de pulmão. In: Braunwald E, Fauci AS Hauser SL, Longo DL, Kasper DL, Larry J. Medicina interna de Harrison. 17th ed. Rio de Janeiro: Mc Graw Hill; 2008. p. 551-62. 